University of Nebraska - Lincoln

DigitalCommons@University of Nebraska - Lincoln

Publications from USDA-ARS / UNL Faculty

U.S. Department of Agriculture: Agricultural

Research Service, Lincoln, Nebraska

2014

\title{
Climate Forecasts for Corn Producer Decision Making
}

\author{
Eugene S. Takle \\ lowa State University, gstakle@iastate.edu \\ Christopher J. Anderson \\ lowa State University \\ Jeffrey Andresen \\ Michigan State University \\ James Angel \\ University of Illinois Urbana-Champaign \\ Roger Wesley Elmore \\ University of Nebraska-Lincoln, roger.elmore@unl.edu
}

See next page for additional authors

Follow this and additional works at: https://digitalcommons.unl.edu/usdaarsfacpub

Takle, Eugene S.; Anderson, Christopher J.; Andresen, Jeffrey; Angel, James; Elmore, Roger Wesley; Gramig, Benjamin M.; Guinan, Patrick; Hilberg, Steven; Kluck, Doug; Massey, Raymond; Niyogi, Dev; Schneider, Jeanne M.; Shulski, Martha D.; Todey, Dennis; and Widhalm, Melissa, "Climate Forecasts for Corn Producer Decision Making" (2014). Publications from USDA-ARS / UNL Faculty. 1411.

https://digitalcommons.unl.edu/usdaarsfacpub/1411

This Article is brought to you for free and open access by the U.S. Department of Agriculture: Agricultural Research Service, Lincoln, Nebraska at DigitalCommons@University of Nebraska - Lincoln. It has been accepted for inclusion in Publications from USDA-ARS / UNL Faculty by an authorized administrator of DigitalCommons@University of Nebraska - Lincoln. 


\section{Authors}

Eugene S. Takle, Christopher J. Anderson, Jeffrey Andresen, James Angel, Roger Wesley Elmore,

Benjamin M. Gramig, Patrick Guinan, Steven Hilberg, Doug Kluck, Raymond Massey, Dev Niyogi, Jeanne M.

Schneider, Martha D. Shulski, Dennis Todey, and Melissa Widhalm 
Earth Interactions - Volume 18 (2014) • Paper No. 5 • Page 1

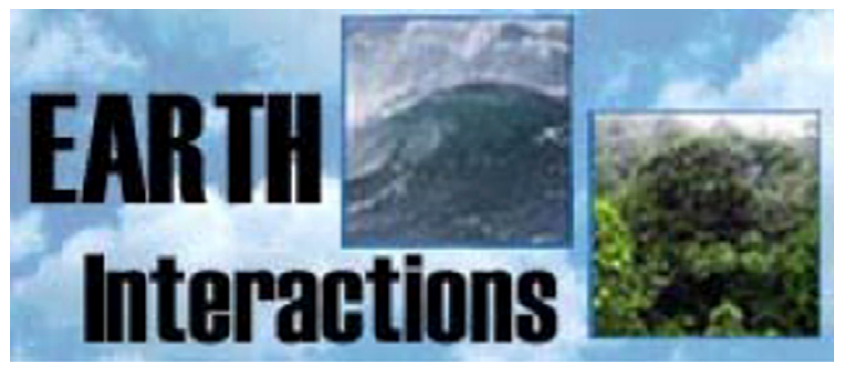

Copyright $\odot$ 2014, Paper 18-05; 22727 words, 1 Figures, 0 Animations, 0 Tables. http://EarthInteractions.org

This article is a U.S. government work, and is not subject to copyright in the United States.

\section{Climate Forecasts for Corn Producer Decision Making}

Eugene S. Takle, ${ }^{\text {a,b }}$ Christopher J. Anderson, ${ }^{\text {b Jeffrey Andresen, }}$ James Angel, ${ }^{d}$ Roger W. Elmore, ${ }^{b}$ Benjamin M. Gramig, ${ }^{e}$ Patrick Guinan, ${ }^{\mathrm{f}}$ Steven Hilberg, ${ }^{\text {g }}$ Doug Kluck, ${ }^{\text {h }}$ Raymond Massey, Dev Niyogi, j, Jeanne M. Schneider, ${ }^{\mathrm{k}}$ Martha D. Shulski, Dennis Todey, ${ }^{\mathrm{m}}$ and Melissa Widhalm ${ }^{\mathrm{n}}$

${ }^{\mathrm{b}}$ Agronomy Department, Iowa State University, Ames, Iowa

${ }^{c}$ Department of Geography, Michigan State University, East Lansing, Michigan

d Illinois State Water Survey, University of Illinois Urbana-Champaign, Champaign, Illinois

${ }^{\mathrm{e}}$ Department of Agricultural Economics, Purdue University, West Lafayette, Indiana

${ }^{\mathrm{f}}$ Department of Soil, Environmental and Atmospheric Sciences, University of Missouri, Columbia, Missouri

${ }^{g}$ Midwestern Regional Climate Center, University of Illinois at Urbana-Champaign, Champaign, Illinois

${ }^{\mathrm{h}}$ National Weather Service Central Region, Kansas City, Missouri

${ }^{i}$ Department of Agriculture and Applied Economics, University of Missouri, Columbia, Missouri USA

${ }^{\mathrm{j}}$ Department of Agronomy, and Department of Earth, Atmospheric, and Planetary Sciences, Purdue University, West Lafayette, Indiana

${ }^{\mathrm{k}}$ Great Plains Agroclimate and Natural Resources Research Unit, Grazinglands Research Laboratory, Agricultural Research Service, USDA, El Reno, Oklahoma

${ }^{1}$ School of Natural Resources, University of Nebraska-Lincoln, Lincoln, Nebraska

${ }^{m}$ Agricultural and Biosystems Engineering, South Dakota State University, Brookings, South Dakota

${ }^{\mathrm{n}}$ Purdue University, West Lafayette, Indiana

Received 10 June 2013; accepted 21 October 2013

${ }^{a}$ Corresponding author address: Eugene S. Takle, 2010 Agronomy Hall, Iowa State University, Ames, IA 50011-1010.

E-mail address: gstakle@iastate.edu

DOI: $10.1175 / 2013 E I 000541.1$ 
Earth Interactions - Volume 18 (2014) • Paper No. 5 • Page 2

\begin{abstract}
Corn is the most widely grown crop in the Americas, with annual production in the United States of approximately 332 million metric tons. Improved climate forecasts, together with climate-related decision tools for corn producers based on these improved forecasts, could substantially reduce uncertainty and increase profitability for corn producers. The purpose of this paper is to acquaint climate information developers, climate information users, and climate researchers with an overview of weather conditions throughout the year that affect corn production as well as forecast content and timing needed by producers. The authors provide a graphic depicting the climate-informed decision cycle, which they call the climate forecast-decision cycle calendar for corn.
\end{abstract}

KEYWORDS: Agriculture systems; Forecasting; Climate forecast; Seasonal forecast; Agriculture forecast; Decision calendar

\title{
1. Introduction
}

The purpose of this paper is to create a communication tool for use by forecast developers and agricultural climate forecast users that will improve the usability and usefulness of climate information. Potential users of the graphic, in addition to crop producers and climate forecasters, include agribusiness product and service providers, extension agents, financial institutions, risk management organizations, and commodity traders. Like producers and forecasters, these users will provide needed input relating to products, information, and timing. Many studies have suggested that improved climate information and forecasts can reduce the risk of economic losses, increase profits, and improve short- and long-term farm management decisions (Crane et al. 2010; Meinke and Stone 2005; Meza et al. 2008). However, integration of climate information and forecasts into farm planning has been slow to occur for numerous reasons including a lack of forecast skill, usability of the information, and relevance of products to specific agricultural decisions (Garbrecht and Schneider 2007).

Here we acquaint climate information developers, climate information users, and climate researchers with an overview of weather conditions throughout the year that affect corn production as well as forecast content and timing needed by producers. Our intent is to engage private and public sectors by integrating multiple time horizons of decisions and time scales of climate and weather information more so than has been done in the past. The climate-based decision cycle for corn graphically illustrates the time of year and lead time of climate forecasts that are relevant to specific agricultural decisions.

There is urgent need for the climate forecast creators and information providers to work more closely with decision-tool developers and information users to improve climate information flow. Climate science researchers from universities and federal laboratories have an opportunity to identify and engage in strategic areas needing further research on assessing predictability, characterizing and narrowing uncertainty, and delivering information for enhancing decision making in relation to food production.

Two recent workshops, the Corn and Climate Workshop (Angel et al. 2009) and the Climate Prediction Applications Science Workshop (NOAA 2011), brought more clearly into focus the lack of publicly available agriculturally relevant information at scales needed for decision making in agriculture, particularly for corn production in the Midwest. At these events the authors held breakout sessions with 
Earth Interactions • Volume 18 (2014) • Paper No. 5 • Page 3

farmers, representatives of farm organizations, agribusiness, insurance, finance, and agriculture extension staff. Forecast content, lead time, products delivered, and modes of delivery were discussed. One theme emerging from these meetings was the need for actionable information, whereby climate products and forecasts are translated into agriculturally relevant impact-specific terms for producers and/or their advisors, for example, "number of days suitable for field work." This outcome is consistent with a growing number of calls for more actionable climate information in other regions (Crane et al. 2010; Dilling and Lemos 2011; Hammer et al. 2001; Hansen and Coffey 2011; Kerr 2011; Klopper et al. 2006). Another was the way that forecast uncertainty is conveyed to information users. The climate forecast decision cycle for corn is an outgrowth of discussions from these events and follow-on meetings of the U.S. Department of Agriculture (USDA) Useful to Usable (U2U) project (http://www.agclimate4u.org).

We discuss the relationship between climate prediction, which we define as being beyond the limits of a weather forecast (i.e., having a lead time of more than 2 weeks), and decision making for food-crop production. For the purpose of introducing the concept, we focus on one crop and one globally important production region to more clearly expose possible opportunities for using climate prediction to increase food production. For these reasons we target growing corn in Iowa, which is located in the central U.S. Corn Belt.

\section{Corn and climate}

One attractive feature of corn as an agronomic crop is that it can be and has been adapted to a range of growing conditions: soils and climate. Furthermore, this crop continues to be improved through selection and breeding as well as management for increased yields.

Because of different sensitivities at various stages of development during the course of the growing season, corn yields respond to individual weather events as well as seasonal climate. Although many weather and climate conditions do not allow corn producers to take preemptive action, climate forecasts have the potential to play a very large role in the decision-making and planning process.

The usefulness of standard, currently provided projections of daily precipitation and temperature is limited. By contrast, specific and, in some cases, more integrated types of projections would be more useful. For instance, a much more actionable piece of information is 3-month-advance forecast of the number of days suitable for field work at planting time or the overwinter climate conditions that determine the winter-long volatility of fall-applied nitrogen fertilizer.

\section{Favorable and unfavorable growing conditions}

Development of actionable forecast information for corn producers requires understanding of the climate impacts on corn growth and management operations. In many years, the amount of water required by the crop exceeds the total precipitation that falls during the growing season. As a result, the ideal climate year for corn production in the U.S. Midwest starts with ample precipitation following fall harvest of the previous crop. This precipitation recharges soil moisture in the upper $2 \mathrm{~m}$ of soil, which provides a buffer against the lack of timely rains the following growing season. It also permits planting of high plant populations, which requires 
Earth Interactions - Volume 18 (2014) • Paper No. 5 • Page 4

relatively more water. During the winter, frozen soils reduce loss of fall-applied nitrogen fertilizer. On the other hand, if the soil is suitably dry and soil temperatures are below $50^{\circ} \mathrm{F}$, fall application of nitrogen fertilizer reduces chances for soil compaction and potential interference with spring planting activities. Weeklong dry spells during the spring accelerate warming of the soil to the $50^{\circ} \mathrm{F}$ threshold to allow planting without causing soil compaction from the weight of machinery. Abundant and timely but not excessive rain, as well as lack of late spring frost (or extended cool periods), allows rapid germination and early growth. Crop development is promoted by temperatures in the range of $82^{\circ}-87^{\circ} \mathrm{F}$ during the day and $67^{\circ}-72^{\circ} \mathrm{F}$ at night, lack of extended periods of cloudiness, and once-a-week rains. These conditions allow windows of opportunity for spraying for pests and supplemental fertilizer application. Lack of early fall frost allows maximum seed fill and kernel weight. Relatively dry conditions after maturity in late September permit the crop to dry down naturally, thereby reducing the need for artificial grain drying after harvest. Weeklong periods without rain allow harvest without soil compaction. Low absolute humidity reduces chances of toxins developing in grain prior to harvest.

Detrimental growing season conditions include extended periods with insufficient plant available soil water and air temperatures above $95^{\circ} \mathrm{F}$. The most vulnerable period for high temperature is during pollination, which normally occurs in mid- to late July. Growth is suppressed by periods of 10 days or more without rain or shorter periods if soil moisture is low at the beginning of the growing season. Nighttime temperatures above $75^{\circ} \mathrm{F}$, high wind, hail, and excessive rainfall all are detrimental to corn development.

\section{Decisions based on climate forecasts}

Corn producers can use climate information for making decisions every month of the year. Commodity markets allow farmers to sell corn at any time, even before the crop is planted. Marketing decisions may require accurate forecasts of climate in regional, national, and international corn growing regions as well as forecasts of on-farm climate. Decisions on crop and cultivar selection, tillage and conservation practices, fertilizer and chemical application, and planting and harvesting options require climate information that, ideally, is at the field scale.

For most efficient use of climate forecast information, the climate forecast developer needs to know the following:

1) Who makes the decisions?

2) What types of decisions are being made?

3) What month and day decisions are being made?

4) What month and day does the weather condition and/or decision impact occur?

5) What specific meteorological variable or combination of variables relate to the consequences of this decision?

6) Are forecasts of variables determined, in item 5, available on calendar dates, in item 3 , with needed lead times determined from the time difference between item 4 and item 3 ?

7) Are combinations of meteorological conditions at different times important? Examples include successive days of heavy rain and early wind 
Earth Interactions - Volume 18 (2014) • Paper No. 5 • Page 5

damage followed later by another stress (e.g., drought) that leads to aflatoxin infection.

8) Which forecast applications are highly site specific and which are regional and/or global?

9) What additional tools are needed to translate meteorological variables into decision aids - such as a crop growth/yield model, soil compaction model, soil erosion model, and calculation of days per week - suitable for field work?

10) What ancillary biological or soil information is needed-such as crop development stage, plant physiology, soil fertility, terrain slope, weeds, insects, and diseases - to allow evaluation of both biotic and abiotic impact on the crop?

11) How are uncertainty metrics and terms associated with the forecasts developed and conveyed to the users: graphs, tables, pdfs, or terciles of skill?

For most efficient use of climate forecast information, the climate forecast user needs to know the following:

1) What is an acceptable level of accuracy for specific variables that will improve decision making?

2) How can the uncertainty metrics and terms associated with the forecasts be interpreted and used?

3) What is the consequence of a good decision versus a bad decision, economically or environmentally, based on the forecast, and what is the consequence of no decision or action?

For improving the value of climate forecast information, the climate researcher needs to know the following:

1) What meteorological variables are needed to improve the climateinformed decisions? Is there linkage of this information to remote, slow time-varying forcing such as ENSO, the Atlantic multidecadal oscillation (AMO), the Pacific decadal oscillation (PDO), and soil moisture?

2) At what points in the annual or interannual decision cycle are these variables needed?

3) How can past information best be collected and archived for effective data mining?

4) How can trends in technology be accounted for in relating past records of yield to climate-related factors?

\section{Climate forecasts beyond 1 year}

Climate forecast information with lead times of a year or more can be used by producers and land owners for decisions on machinery purchases, marketing, refining annual rental contracts, and installing conservation practices such as grass waterways and for the use of cover crops. Decadal or longer climate projections can affect decisions on land purchase or sale, estate planning, or installation of irrigation or conservation structures such as riparian zone planting or drainage tile.

\section{The corn forecast-decision cycle}

Figure 1 illustrates an example of the forecast-decision cycle for communicating to climate forecast producers the nature and timing of forecasts that are useful to 


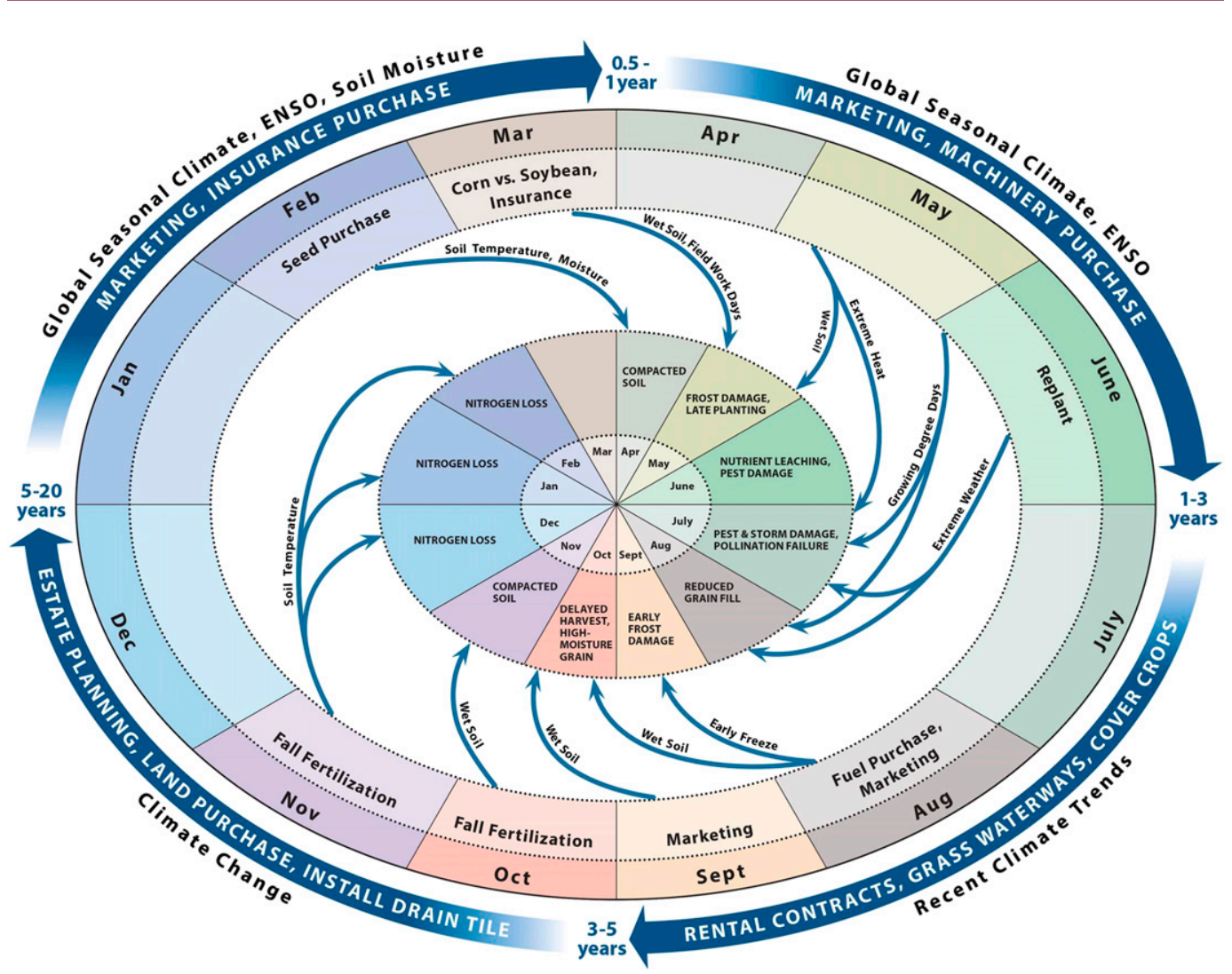

Figure 1. Climate-based decision cycle for corn. The outer calendar identifies the time of year management decisions are made. The inner calendar depicts the soil or crop impact, and the label on the arrow identifies the weather or soil conditions relevant to the impact. Length of the arrow gives the lead time of climate forecasts that links the specific agricultural decisions to soil or crop impacts.

corn producers. Decision calendars are commonly assembled in a matrix format to provide a listing of information in relation to timing of decisions. The forecastdecision cycle provides a unique depiction of the cyclic and overlapping time horizons affecting the decision process.

The outer calendar in Figure 1 provides sample decisions that are made in certain months that require specific climate forecast information to be available at that time. The labeled arrow indicates the climate-related factor needed to make that decision. The arrowhead lands on the inner calendar at the time that the soil or crop impact of the management action influenced by climate forecast information occurs. The length of the arrow provides the issue date and lead time needed for the forecast.

Large arrows surrounding the outer calendar provide example decisions that have climate forecast lead times of a half a year or more, typically beyond the normal range of seasonal climate forecasts. These decisions could be informed by trends in climate change or emerging new science on interannual variability and probability of extreme events, with the latter two likely having a larger impact than the climate change trend over one or a few years into the future. 
Earth Interactions - Volume 18 (2014) • Paper No. 5 • Page 7

A decision on fall application of nitrogen fertilizer (anhydrous ammonia) will illustrate use of the climate forecast-decision cycle. A farmer may be able to take advantage of favorable prices for purchasing fertilizer in the fall compared to the following spring. Fall application also can be completed at a time that does not interfere with tillage or planting operations. The possible downside of fall application is that if soils are too warm and not frozen substantial nitrogen will be lost because of volatilization. So the farmer, making the decision in November, needs a forecast of the likelihood that soils will be continuously frozen or snow covered from shortly after application until about 1 March. For this decision, the farmer is not concerned about air temperature, precipitation, winds, humidity, etc. Even a forecast that lacks skill in these variables will be useful in making this decision if it is accurate for predicting frozen soils.

As another example, a month-ahead forecast of wet soils in fall would warn of harvest delay and interference with natural in-field grain dry down, possibly leading to high-moisture grain at harvest. A delay in harvest date or increased costs due to the need for artificial drying of grain will influence timing of crop delivery to market and expectations for profitability.

There are follow-on climate-sensitive decisions that are not represented. For instance, the springtime decisions of purchasing fertilizer and herbicides are connected to the decision to plant corn versus soybeans. Similarly, replant decisions will change marketing options.

Individual Midwest corn producers and corn producers outside the central Midwest will require a slightly altered cycle of decisions and timelines. Figure 1 is meant to be illustrative. Producers of other crops can use this example to create calendars reflecting their own needs as a way of opening the dialog on climate needs with their climate services provider or, collectively, as feedback to the National Oceanic and Atmospheric Administration (NOAA).

\section{Summary}

We developed a cyclic depiction of a corn forecast-decision cycle for an agricultural application: in our example to corn production decisions in the central Midwest. In contrast to a tabular listing of data, the cyclic calendar clearly reveals the timing, lead times, and variables of highest interest from climate forecasts throughout the year. Climate forecasts typically will have different skill levels at different times of the year and for different variables. This cycle is intended to open the dialog between climate forecast providers and climate forecast users on the linkage between specific forecast time of year, lead time, and combinations of variables with specific decisions made by producers. This allows the skill of forecasts to be measured more directly in terms of forecast use rather than conventional meteorological components such as pressure patterns, monthly precipitation, or monthly temperature. Through dialog among information providers, information users, and the research community, climate services for this significant agricultural sector can be meaningfully enhanced using a unique forecast-decision cycle perspective. The potential exists for this approach to be expanded for other crops and regions.

Acknowledgments. This report is a product of the project Useful to Usable (U2U): Transforming Climate Variability and Change Information for Cereal Crop Producers, an 
Earth Interactions • Volume 18 (2014) • Paper No. 5 • Page 8

interdisciplinary research and extension project involving 10 Midwestern universities supported by USDA-NIFA Award 2011-68002-30220.

\section{References}

Angel, J., and Coauthors, 2009: Corn and climate report: An overview of climate science in service of Midwest agriculture. U.S. Climate Change Science Program Rep., 67 pp. [Available online at http://climate.engineering.iastate.edu/Document/Corn_and_Climate_Report.pdf.]

Crane, T. A., C. Roncoli, J. Paz, N. Breuer, K. Broad, K. T. Ingram, and G. Hoogenboom, 2010: Forecast skill and farmers' skills: Seasonal climate forecasts and agricultural risk management in the southeastern United States. Wea. Climate Soc., 2, 44-59.

Dilling, L., and M. C. Lemos, 2011: Creating usable science: Opportunities and constraints for climate knowledge use and their implications for science policy. Global Environ. Change, 21, 680-689.

Garbrecht, J. D., and J. M. Schneider, 2007: Climate forecast and prediction product dissemination for agriculture in the United States. Aust. J. Agric. Res., 58, 966-974.

Hammer, G. L., J. W. Hansen, J. G. Phillips, J. W. Mjelde, H. Hill, A. Love, and A. Potgieter, 2001: Advances in application of climate prediction in agriculture. Agric. Syst., 70, 515-553.

Hansen, J., and K. Coffey, 2011: Agro-climate tools for a new climate-smart agriculture. CCAFS Rep., 4 pp.

Kerr, R. A., 2011: Adaptation to climate change. Time to adapt to a warming world, but where's the science? Science, 334, 1052-1053.

Klopper, E., C. H. Vogel, and W. A. Landman, 2006: Seasonal climate forecasts - potential agriculturalrisk management tools? Climatic Change, 76, 73-90.

Meinke, H., and R. C. Stone, 2005: Seasonal and inter-annual climate forecasting: The new tool for increasing preparedness to climate variability and change in agricultural planning and operations. Increasing Climate Variability and Change, J. Salinger, M. V. K. Sivakumar, and R. P. Moth, Eds., Springer-Verlag, 221-253.

Meza, F. J., J. W. Hansen, and D. Osgood, 2008: Economic value of seasonal climate forecasts for agriculture: Review of ex-ante assessments and recommendations for future research. J. Appl. Meteor. Climatol., 47, 1269-1286.

NOAA, 2011: 9th Annual Climate Prediction Applications Science Workshop report. NOAA Rep., $32 \mathrm{pp}$. [Available online at http://climate.engineering.iastate.edu/Document/CPAS\% 20Workshop_Final_low\%20rez.pdf.]

Earth Interactions is published jointly by the American Meteorological Society, the American Geophysical Union, and the Association of American Geographers. Permission to use figures, tables, and brief excerpts from this journal in scientific and educational works is hereby granted provided that the source is acknowledged. Any use of material in this journal that is determined to be "fair use" under Section 107 or that satisfies the conditions specified in Section 108 of the U.S. Copyright Law (17 USC, as revised by P.IL. 94-553) does not require the publishers' permission. For permission for any other from of copying, contact one of the copublishing societies. 